\title{
Media Influence on Sexual Activity and Contraceptive Use Amongst Students of University of Jos, Jos Plateau State Nigeria
}

\author{
Charles Ujunwa Anyaka ${ }^{1, ~}$, Christopher Orokpo Egbodo ${ }^{1}$, Makshwar Luka Kahansim \\ Amaka Ngozi Ocheke', John Edeoja Edeh ${ }^{2}$ \\ ${ }^{1}$ Department of Obstetrics and Gynaecology, University of Jos, Jos University Teaching Hospital, Jos, Nigeria \\ ${ }^{2}$ Department of Mass Communication, University of Jos, Jos, Nigeria
}

Email address:

charlesanyaka@yahoo.com (C. U. Anyaka)

${ }^{*}$ Corresponding author

\section{To cite this article:}

Charles Ujunwa Anyaka, Christopher Orokpo Egbodo, Makshwar Luka Kahansim, Amaka Ngozi Ocheke, John Edeoja Edeh. Media Influence on Sexual Activity and Contraceptive Use Amongst Students of University of Jos, Jos Plateau State Nigeria. Journal of Gynecology and Obstetrics. Vol. 8, No. 5, 2020, pp. 141-147. doi: 10.11648/j.jgo.20200805.13

Received: August 30, 2020; Accepted: September 17, 2020; Published: October 7, 2020

\begin{abstract}
Introduction: The Youth are active consumers of media content where issues pertaining to sexual activity and contraceptives could be seen. Information derivable from the media can reduce the burden of reproductive health. Therefore, examining the influence of media on sexual behaviour and contraceptive use of students may assist policy makers to strategize on providing solutions to these problems. Objective: The general objective of this study was to examine the influence of media on sexual activity and contraceptive use among students at the University of Jos, Plateau State. Methods: A descriptive crosssectional study where 278 students of general studies were selected using a multistage random sampling technique. Individuals were subsequently chosen at random until a statistically determined sample size was achieved. Statistical Package for Social Sciences (SPSS version 20) software was utilized for data analysis. Results: The mean age of respondents was 22.3 years Students that were $\leq 20 \mathrm{yrs}$ constituted the largest group of respondents $(49.6 \%)$. Most of the students (77\%) agreed that media influences sexual behaviour with the Internet/social media (39.3\%) having the most influence. Most of the respondents (87.4\%) had heard of contraceptives from the media, most from the Internet/social media (42.4\%) while the male condom (46.5\%) was the most known type of contraceptive. Most of the respondents (77.7\%) felt that contraceptive information in the media encouraged engagement in safe sex. There was a significant statistical association between information from media and influence on sexual activity and also influence on use of contraceptives. There was also significant statistical association between information on contraceptives from media and engagement in safe sexual activity. Significant number of the students $(42.6 \%)$ agreed while $40.0 \%$ disagreed that the media should be a platform for sex education to students. Most of the students $(87.4 \%)$ agreed that contraceptives information in media can lead to reduced incidence of unwanted pregnancies among students. Most of the students (86.7\%) agreed that contraceptives information in media can lead to reduced incidence of STIs and HIV/AIDS among students. Conclusion: Media content is seen among the top sexual educators amongst students. Mass media plays an important role in improving contraceptive use among students. This finding provides a window of opportunity for improving contraceptive utilization in the country through an improved and sustained use of the mass media to disseminate family planning information.
\end{abstract}

Keywords: Media, Influence, Sexual Activity, Contraceptive Use, Jos

\section{Introduction}

Adolescent sexual behaviour has been recognized as an important health, social and demographic concern in the developing world [1]. Adolescent pregnancy is associated with adverse maternal, fetal and neonatal outcomes [2, 3]. Teenage girls who get pregnant suffer from social and economic consequences and they are more likely to drop out of school. Furthermore, unwanted pregnancy poses a big problem among young adult in developing countries [4]. 
Youth are active consumers of media content and often report that the media are among the top sexual educators. [5, 6]It has also been established that many youths report that their parents do not give them sufficient information about sexual subjects during adolescence [5]. This inevitably prompts youths to seek out information from various sources without authenticating the veracity of such sensitive information which could be offensive or graphic to their own disadvantage on handful of occasion. [6, 7]

Adolescents are keen users of the information derivable in the media, and concern has been raised about the influence of media outlets on sexual behaviour and the expectations of these adolescents at a critical developmental stage. [6, 7] There is documented proof in a number of countries of sexual debut amongst adolescents at a very young age [8].

Students who are undergoing tertiary education have greater freedom from home, with new friendships and romantic or sexual relationships [8]. These new opportunities and freedom come with high risk behaviours such as unplanned and unprotected sex sometimes with multiple sexual partners [9]. These new attitudes are usually driven by curiosity, peer pressure and sexual maturation. [7, 8] The result of such sexual experimentation includes unplanned and or unwanted pregnancies that leads to abortions, (mostly unsafe), and sexually transmitted infections including HIV/AIDS [10, 11]. The level of prostitution and all forms of promiscuous behaviour associated with students of tertiary institutions and other anti-social sexual behaviours, coupled with the widespread of sexually transmitted infections and teenage pregnancy amongst undergraduates is of great concern to the society [9]. The absence of contraceptive services in tertiary institutions has further led to increased rates of unwanted pregnancy, unsafe abortions and STIs among undergraduates of these institutions [12,13].

Low level of utilization of contraceptives has been associated with high rates of unwanted pregnancies and unsafe abortions among Sub-Saharan Africa youth ${ }^{14}$. A study conducted among nursing female students at University of Calabar in Nigeria revealed that $55 \%$ of students were sexually active while $37 \%$ had knowledge of family planning especially condom use [15]. In a similar study, more than half (51\%) of the students who had unwanted pregnancy ended with abortion [15]. Low utilization of contraception has also been attributed to limited capacity of the health care system and structure within which family planning services are offered [16]. Furthermore, individual factors such as risk perception, fear of side effects, opposition from male partners, health service limitations and insufficient knowledge needed to make informed choices have been reported as barriers for utilization of contraception. [17, 18]

In most sub-Saharan African countries, more than $70 \%$ of young women begin sexual activity during adolescent period - this to a large extent is as a result of exposure to media effect $[10,15]$.

It is against this background that this study therefore sought to examine the influence of media on sexual activity and contraceptive use among students in university of Jos,
Plateau state Nigeria. The increase of sexual violence, teenage pregnancies, illicit abortions, and sexually transmitted infections, especially human immunodeficiency virus (HIV), among undergraduates in sub-saharan African countries [19], makes this research more timely.

\section{Methodology}

\subsection{Study Area and Study Design}

This descriptive cross-sectional study was carried out at the University of Jos among first year students who compulsorily take General studies courses. The city is located on the Jos Plateau with coordinates of $9.8965^{\circ} \mathrm{N}$, $8.8583^{\circ} \mathrm{E}$ at an elevation of about 1,238 metres or 4,062 feet high above sea level [20]. Jos is a city in north-central Nigeria and the administrative capital of Plateau State.

This was a descriptive, cross-sectional study.

\subsection{Sample Size}

The sample size was determined using the formula (see below) for sample size determination in cross-sectional studies. Using a 95\% confidence level and accuracy of 5\% and a prevalence of sexual activity among undergraduates of $76.4 \%$ based on a previous study in Nigeria [21]; the sample size was calculated using the formula below:

$$
\text { Sample Size }=\mathrm{z}^{2} \mathrm{pq} / \mathrm{d}^{2}
$$

Where $Z=1.96 ; p=0.764 ; q=(1-p)=0.236$ and $d=0.05$

By computing, sample size $=277$

However considering an attrition rate of $10 \%=27.7$, so sample size was $277+28=305$ participants

Sample collection: Pretested semi-structured questionnaires were administered to randomly selected students of general studies who are made up of all the faculties of the University of Jos. The 100 level ( $1^{\text {st }}$ year) students taking general studies as compulsory courses are grouped into 5 classes for expediency into

1. Faculties of Natural sciences, Engineering, Medical sciences and Pharmacy

2. Faculties of Social and Management sciences

3. Faculties of arts and environmental sciences

4. Faculty of Education

5. Faculties of Law, Agricultural sciences and Veterinary medicine.

Each class had $305 / 5=61$ pretested semi-structured questionnaires distributed. The students who declined consent were not included in the study. Simple random sampling technique was then used in selecting this number of students per class. Of 61 questionnaires shared on each lecture day, weekly for five weeks between $24^{\text {th }}$ April 2018 and $29^{\text {th }}$ May 2018, however a total of $278(91.1 \%)$ students returned their questionnaires with all questions completely answered.

This self-administered questionnaire was divided into four sections. The first section comprised of sociodemographic characteristics of respondents; the second section dealt with 
influence of media and sexual behaviour; the third section examined the influence of media on the use of contraceptives; and the last section dealt with the influence of contraceptives in media on sexual behaviour of students. All questionnaires were checked for completeness and entered into statistical package for social sciences (SPSS version 20) software.

Data Analyses: Chi-square analysis was done and statistical significance tested. Data was summarized and presented in tables. Using a five-point Likert scale (strongly agree, agree, undecided, disagree, strongly disagree), outcome variables for the attitudes of respondents were scored.

Ethical issues: Ethical approval to conduct this study was obtained from the Research Ethics Committee of Jos University Teaching Hospital, Jos, Plateau state. In addition, verbal informed consent was obtained from each respondent.

\section{Results}

There were 278 students, 189 males and 89 females. Table 1 below shows that students that are $\leq 20 \mathrm{yrs}$ constituted the largest group of students $(49.6 \%)$ while those that are $\geq 35 \mathrm{yrs}$ constituted the least $(3.6 \%)$. The mean age was 22 years. There were more male students $(67.9 \%)$. Most of the respondents (66.2\%) were Christians and single (92.8\%).

Table 1. Sociodemographic characteristics of the respondents $(N=278)$.

\begin{tabular}{llll}
\hline Characteristics & & Frequency & Percentage \\
\hline Age range of students (Years) & & 49.6 \\
& $\leq 20 \mathrm{yrs}$ & 138 & 25.1 \\
& $21-25 \mathrm{yrs}$ & 70 & 15.9 \\
& $26-30 \mathrm{yrs}$ & 44 & 5.8 \\
& $31-35 \mathrm{yrs}$ & 16 & 3.6 \\
& $\geq 35 \mathrm{yrs}$ & 10 & 67.9 \\
Sex of students & Male & & 32.1 \\
& Female & 189 & 66.2 \\
Religion of students & Christian & 89 & 33.8 \\
& Moslem & & \\
& Traditional & 184 & \\
& Others & & 92.8 \\
Marital Status & Single & 94 & 7.2 \\
& & 20.9 \\
Degree program (faculty) & Married & & 20.1 \\
Natural sciences, Engineering, Health sciences and Pharmacy & 258 & 18.7 \\
Social and Management sciences & 20 & 20.9 \\
Arts and Environmental sciences & No \\
Education & 58 & 19.4 \\
\hline Law, Agricultural sciences and Veterinary medicine. & 56 & \\
\hline
\end{tabular}

Table 2 below shows that $29.6 \%$ of the students were sexually active and of these, $29.6 \%$ were aged $\leq 20 \mathrm{yrs}$. The mean age was 22 years. Most of the students (77\%) agreed that media influences sexual behaviour with the Internet/social media (39.3\%) having the most influence. Most of the respondents ( $87.4 \%$ ) had heard of contraceptives in media, most from the Internet/social media (42.4\%). The male condom $(46.5 \%)$ is the contraceptive most respondent have heard from the media. Most of the respondents (77.7\%) feel that contraceptive information in media encourage engagement in safe sex.

Table 2. Sexual behaviour and contraceptives usage among students $(N=278)$.

\begin{tabular}{|c|c|c|}
\hline Characteristics & Frequency (n) & $\%$ \\
\hline \multicolumn{3}{|c|}{ Are you sexually active } \\
\hline No & 202 & 70.4 \\
\hline Yes & 76 & 29.6 \\
\hline \multicolumn{3}{|c|}{ Age at first sex (years) } \\
\hline$\leq 20$ yrs & 20 & 26.3 \\
\hline $22-25 y r s$ & 28 & 36.8 \\
\hline $26-30 y r s$ & 14 & 18.4 \\
\hline$\geq 35 \mathrm{yrs}$ & 5 & 6.7 \\
\hline \multicolumn{3}{|c|}{ Does Media influence sexual activity } \\
\hline No & 64 & 23.0 \\
\hline Yes & 214 & 77.0 \\
\hline \multicolumn{3}{|c|}{ Which media influence your sexual behaviour } \\
\hline Radio & 36 & 16.8 \\
\hline Television & 82 & 38.3 \\
\hline
\end{tabular}




\begin{tabular}{|c|c|c|}
\hline Characteristics & Frequency (n) & $\%$ \\
\hline Newspaper & 12 & 5.6 \\
\hline Social media/internet & 84 & 39.3 \\
\hline \multicolumn{3}{|c|}{ Have you heard of contraceptives from media } \\
\hline No & 35 & 12.6 \\
\hline Yes & 243 & 87.4 \\
\hline \multicolumn{3}{|c|}{ If yes, which contraceptive did you hear from media } \\
\hline Male condom & 113 & 46.5 \\
\hline Female condom & 8 & 3.4 \\
\hline Oral pills & 56 & 23.1 \\
\hline Injectables & 20 & 8.2 \\
\hline Implants & 12 & 4.9 \\
\hline IUCD & 24 & 9.8 \\
\hline Vasectomy (Male method) & 10 & 4.1 \\
\hline \multicolumn{3}{|c|}{ Source of information about contraceptives } \\
\hline Friends & 32 & 13.2 \\
\hline Radio & 10 & 4.1 \\
\hline Television & 88 & 36.2 \\
\hline Newspaper & 10 & 4.1 \\
\hline Social media/internet & 103 & 42.4 \\
\hline \multicolumn{3}{|c|}{ Does contraceptive information in media encourage engagement in safe? Sex } \\
\hline No & 62 & 22.3 \\
\hline Yes & 216 & 77.7 \\
\hline
\end{tabular}

Table below showed that $42.6 \%$ of the students agree while $40.0 \%$ disagree that the media should be a platform for sex education to students. Most of students $(72.7 \%)$ agree that Media has Influence on the use of contraceptives among students. Most of the students $(74.4 \%)$ agree that contraceptives information in media can be effective in increasing healthy sexual behaviours among students. Most of the students $(87.4 \%)$ agree that contraceptives information in media can lead to reduced incidences of unwanted pregnancies among students. Most of the students (86.7\%) agree that contraceptives information in media can lead to reduced incidences of STIs and HIV/AIDS among students

Table 3. Attitudes of students to media, sexual activity and contraceptives ( $n=278)$.

\begin{tabular}{|c|c|c|c|c|c|}
\hline Variables & $\begin{array}{l}\text { Strongly agree } \\
\text { n }(\%)\end{array}$ & $\begin{array}{l}\text { Agree } \\
\text { n (\%) }\end{array}$ & $\begin{array}{l}\text { Undecided } \\
\text { n (\%) }\end{array}$ & $\begin{array}{l}\text { Disagree } \\
\text { n (\%) }\end{array}$ & $\begin{array}{l}\text { Strongly disagree } \\
\text { n (\%) }\end{array}$ \\
\hline The media should be a platform for sex education to students & $84(30.2)$ & $35(12.6)$ & $45(16.2)$ & $34(12.2)$ & $80(27.8)$ \\
\hline Media has Influence on the use of contraceptives among students & $120(43.2)$ & $82(29.5)$ & $18(6.5)$ & $24(8.6)$ & $34(12.2)$ \\
\hline $\begin{array}{l}\text { Contraceptives information in media can be effective in increasing } \\
\text { healthy sexual behaviours among students }\end{array}$ & $140(50.3)$ & $67(24.1)$ & $29(10.4)$ & $21(7.6)$ & $21(7.6)$ \\
\hline $\begin{array}{l}\text { Contraceptives information in media can lead to reduced } \\
\text { incidences of unwanted pregnancies among students }\end{array}$ & $151(54.3)$ & $92(33.1)$ & $10(3.6)$ & $13(4.7)$ & $12(4.3)$ \\
\hline $\begin{array}{l}\text { Contraceptives information in media can lead to reduced } \\
\text { incidences of STIs and HIV/AIDS among students }\end{array}$ & $163(58.6)$ & $78(28.1)$ & $15(5.4)$ & $8(2.9)$ & $14(5.0)$ \\
\hline
\end{tabular}

Table 4 below shows that there is significant statistical association between information from media and influence on sexual activity and also influence on use of contraceptives. It also shows that there is significant statistical association between information on contraceptives from media and engagement in safe sexual activity.

Table 4. Relationship between Attitudes of students to sexual activity, contraceptives with information from media.

\begin{tabular}{|c|c|c|c|c|c|}
\hline \multirow{2}{*}{$\begin{array}{l}\text { Variable } \\
\text { Information from media }\end{array}$} & \multicolumn{2}{|c|}{ Influence on sexual activity } & \multirow{2}{*}{ Chi square } & \multirow{2}{*}{ df } & \multirow{2}{*}{$P$} \\
\hline & No & Yes & & & \\
\hline No & 24 & 40 & 17.94 & 1 & $<0.001$ \\
\hline Yes & 52 & 162 & & & \\
\hline
\end{tabular}

\begin{tabular}{|c|c|c|c|c|c|}
\hline \multirow{2}{*}{$\begin{array}{l}\text { Variable } \\
\text { Information from media }\end{array}$} & \multicolumn{2}{|c|}{ Influence on use of contraceptives } & \multirow{2}{*}{ Chi square } & \multirow{2}{*}{ df } & \multirow{2}{*}{$P$} \\
\hline & No & Yes & & & \\
\hline No & 15 & 20 & 53.15 & 1 & $<0.001$ \\
\hline Yes & 11 & 232 & & & \\
\hline
\end{tabular}

\begin{tabular}{llllll}
\hline Variable & \multicolumn{2}{l}{ Encourages to engage in safe sexual activity } & \multirow{2}{*}{ Chi square } & df & \multirow{2}{*}{$\boldsymbol{P}$} \\
\hline Information on Contraceptives from media & No & 15 & Yes & 20.00 & 1 \\
\hline No & 47 & 11 & & \\
Yes & 47 & 205 & & \\
\hline
\end{tabular}




\section{Discussion}

From our study $77 \%$ of the respondents were of the opinion that media has influence on sexual behaviour. Social media with $39.3 \%$ represents the source with the most influence on sexual behaviour. This is similar to previous reports $[21,22]$. This finding may be related with affinity by young persons to social media using the internet which serves as source for easy information on most current issues for which sexual activity is not exempted. They are at risk of uncensored messages which as a result of peer pressure may lure them into sexual activity. [21] Social media is a growing platform that potentially gives out health promotion and disease prevention messages [23, 24]. Others however have opined that Internet and social media might also have negative health consequences due to erroneous belief of privacy leading to more illicit behavior and discussion around drinking, sex, violence coupled with less parental monitoring $[25,26]$.

From our study, $87.4 \%$ of the respondents have heard of contraceptives from media. This finding is similar to other reports.[27] It is also seen that the male condom is the contraceptive having the highest awareness with $46.5 \%$. This finding is also similar to other reports. [28] This may be due to the fact that male condoms are more easily accessible, cheap and readily available and has been noted to also have protection against some sexually transmissible infections. [16, 17] Very few students (8.4\%) were aware of the female condom from the media. This calls for more education and promotion of female condom and other family planning methods by various stakeholders to make it readily available to our women of reproductive age.

Mass media has been shown to play an important role in improving contraceptive use among Nigerian women. [29, 30] Adolescent female students should be provided opportunities to access reproductive health information to navigate this period of development successfully.

From our study, $77.7 \%$ of the respondents were of the view that contraceptive information in media would encourage safe sex. This is similar with other reports with such percentages. [31] This is a commendable finding and it shows that all the campaigns against unprotected sex with its consequent effects is having its desired impact especially on the young who indeed could be in harm's way. So more of such information is encouraged especially in the media as it would get to our youths with positive impact. A recent study revealed that $86 \%$ of the recent decline in teen pregnancies could be attributed to increased contraceptive use, and only $14 \%$ was attributable to increased abstinence. [32] This is also in keeping with reports by other authors which showed that countries that widely encourage birth control products in media have a much lower rate of teen pregnancy. [33]

From our study, $42.6 \%$ of the students agreed while $40.0 \%$ disagreed that the media should be a platform for sex education to students. The views on this appears equally split, this may be from reports showing the mass media having advantages by providing necessary information for young people on sexual health and healthy sexual relationships. [7] However this is at variance with others studies which have shown that mass media negatively influences teens in their sexual behaviors. [7, 34] Most of the students (87.4\%) agree that contraceptives in media can lead to reduced incidences of unwanted pregnancies among students. Most of the students (86.7\%) agree that contraceptives in media can lead to reduced incidences of STIs and HIV/AIDS among students. This is consistent with findings from other authors, where advocacy was made for promotion of contraceptives in media with its immense beneficial effect in reduction of unintended pregnancies and STIs. [30, 35]

The limitation of this study: there were some very personal and sensitive questions which some of the respondents did not feel very comfortable answering, so they had to be reassured of confidentiality again.

\section{Conclusion}

Most of the respondents in this study agree that media influences sexual behavior and most have heard of contraceptives from the media and opined that media has influence on contraceptive use. Most of the students agreed that contraceptives information in media can be effective in increasing healthy sexual behaviours among students.

On the basis of these findings, it is recommended that that young people be wholistically educated on the media especially on the proper use of the internet. Undergraduates in schools in this country are required to compulsorily take a course in general studies as a way of acquiring rudimentary knowledge in this arena, tertiary institutions should use this opportunity to educate students on how to use the media to access proper and useful information on sexual issues and use of contraceptives to reduce the incidences of unwanted pregnancies and STIs.

\section{References}

[1] Liang M, Simelane S, Fortuny Fillo G, Chalasani S, Weny K, Salazar Canelos P, Jenkins L, Moller AB, Chandra-Mouli V, Say L, Michielsen K, Engel DMC, Snow R. The State of Adolescent Sexual and Reproductive Health J Adolesc Health. $2019 \quad$ Dec; $65 \quad$ (6S): S3-S15. doi: 10.1016/j.jadohealth.2019.09.015. PMID: 3176100 .

[2] Leftwich HK, Alves MV. Adolescent Pregnancy. Pediatr Clin North Am. 2017 Apr; 64 (2): 381-388. doi: 10.1016/j.pcl.2016.11.007. Epub 2017 Jan 3. PMID: 28292453.

[3] Kassa GM, Arowojolu AO, Odukogbe AA, Yalew AW. Prevalence and determinants of adolescent pregnancy in Africa: a systematic review and Meta-analysis. Reprod Health. 2018 Nov 29; 15 (1): 195. doi: 10.1186/s12978-018-0640-2. PMID: 30497509. 
[4] Sahin NH. Male university students' views, attitudes and behaviors towards family planning and emergency contraception in Turkey. J Obstet Gynaecol Res. 2008, 34 (3): 392-398. 10.1111/j.1447-0756.2007.00698.x.

[5] Brown JD. Mass media influences on sexuality. J Sex Res. 2002; 39 (1): 42-45.

[6] Malamuth NM, Impett EA. Research on sex in the media: what do we know about effects on children and adolescents? In: Singer DG, Singer JL, editors. Handbook of Children and the Media. Thousand Oaks, CA: Sage Publications; 2001: 269-287.

[7] Werner-Wilson RJ, Fitzharris JL, Morrissey KM. Adolescent and parent perceptions of media influence on adolescent sexuality. Adolescence. 2004; 39 (154): 303-313.

[8] UNAIDS (2002), Report on the Global HIV/AIDS epidemic. Geneva: UNAIDS Rich M. Virtual Sexuality: The Influence of Entertainment Media on Sexual Attitudes and Behavior. Washington, DC. The National Campaign to Prevent Teen and Unplanned Pregnancy; 2008. Available from: $\mathrm{http}: / /$ www.thenationalcampaign.org/resources/monster/MM 1.0.pdf. Accessed August 10, 2020.

[9] Juliet Iwelunmor, Sarah Blackstone, Ucheoma Nwaozuru, Donaldson Conserve, Patricia Iwelunmor, John E Ehiri. Sexual and reproductive health priorities of adolescent girls in Lagos, Nigeria: findings from free-listing interviews Int $\mathrm{J}$ Adolesc Med Health. 2017 May 17; 30 (5). PMID: 28525320.

[10] Mthembu Z, Maharaj P, Rademeyer S. "I am aware of the risks, I am not changing my behaviour": risky sexual behaviour of university students in a high-HIV context. Afr J AIDS Res. 2019 Sep; 18 (3): 244-253. doi: 10.2989/16085906.2019.1655075. PMID: 31575340.

[11] Adeniji AO, Adekanle DA, Akindele RA. Emergency contraception: knowledge and practices of tertiary students in Osun State, South Western Nigeria. Gynecol Obstet (Sunnyvale). 2014; 4: 196.

[12] Ugoji FN. An Examination of university students' attitude to contraceptive Use. Am Int J Soc Sci. 2013; 2 (1): 18-22.

[13] Nibabe WT, Mgutshini T. Emergency contraception amongst female college students-knowledge, attitude and practice. Afr J Prim Health Care Fam Med. 2014; 6 (1): 538.

[14] Gbagbo FY, Nkrumah J. Family planning among undergraduate university students: a CASE study of a public university in Ghana BMC Womens Health. 2019 Jan 17; 19 (1): 12. doi: 10.1186/s12905-019-0708-3. PMID: 30654787.

[15] Ndifon WO, Ogaji DST, Etuk SJ. Sexuality, contraception and unwanted pregnancy among female student nurses in Calabar, Nigeria. Benin J Postgrad Med. 2006, 8 (1): 12-21.

[16] Masoda M, Govender I. Knowledge and attitude about and practices of condom use for reducing HIV infection among Goma University students in the Democratic Republic of Congo. South Afr J Epidemiol Infect. 2013, 28 (1): 61-68.

[17] Abiodun OM, Balogun OR. Sexual activity and contraceptive use among young female students of tertiary educational institutions in Ilorin, Nigeria. Contraception. 2009, 79 (2): 146-149. 10.1016/j.contraception.2008.08.002. PMID: 19135573.

[18] Haggan JE. Contraceptive knowledge, perceptions and use among adolescents in selected senior high schools in Central Region of Ghana. J Soci Res. 2012, 3 (2): 170-180.

[19] Olasode OA. Sexual behaviour in adolescents and young people attending a sexually transmitted disease clinic, Ile Ife, Nigeria. Indian J Sex Transm Dis. 2007; 28 (2): 83-86.

[20] Jos. (2018, January 26). In Wikipedia, The Free Encyclopedia. Retrieved 13: 33, 16 ${ }^{\text {th }}$ August 2020, from https://en.wikipedia.org/w/index.php?title $=$ Jos\&oldid $=822538$ 327.

[21] Bajoga UA, Atagame KL, Okigbo CC Media Influence on Sexual Activity and Contraceptive Use: A Cross Sectional Survey among Young Women in Urban Nigeria. Afr J Reprod Health. 2015 Sep; 19 (3): 100-10.

[22] Asekun-Olarinmoye OS, Asekun-Olarinmoye E, Adebimpe WO, Omisore AG Effect of mass media and Internet on sexual behavior of undergraduates in Osogbo metropolis, Southwestern Nigeria Adolescent Health, Medicine and Therapeutics 2014 (5) Pages 15-23.

[23] Stockwell MS, Kharbanda EO, Martinez RA, Lara M, Vawdrey D, Natarajan K, Rickert VI. Text 4 Health: impact of text message reminder-recalls for pediatric and adolescent immunizations. Am J Public Health. 2012 Feb; 102 (2): e1521. doi: 10.2105/AJPH.2011.300331.

[24] Wong CA, Merchant RM, Moreno MA. Using social media to engage adolescents and young adults with their health. In Healthcare. 2014 Dec 31; 2 (4): 220-4.

[25] Houlihan D, Houlihan M. Adolescents and the social media: the coming storm. J Child Adolesc Behav. 2014; 2: e105. doi: $10.4172 /$ jcalb.1000e 105 .

[26] Landry M, Turner M, Vyas A, Wood S. Social Media and Sexual Behavior Among Adolescents: Is there a link? JMIR Public Health Surveill. 2017 May 19; 3 (2): e28. doi: 10.2196/publichealth.7149. PMID: 28526670.

[27] Owonikoko KM, Bello-Ajao HT, Fawole AA, Adeniji AO. Determinants of sexual activities and contraceptive usage among adolescents in high schools in Ogbomoso, a semiurban settlement in Nigeria. Int J Adolesc Med Health. 2016 May 1; 28 (2): 161-8. doi: 10.1515/ijamh-2015-0001.

[28] Magreat J Somba, Milline Mbonile, Joseph Obure Michael J Mahande. Sexual behaviour, contraceptive knowledge and use among female undergraduates' students of Muhimbili and Dar es Salaam Universities, Tanzania: a cross-sectional study BMC Womens Health 2014 Aug 7; 14: 94. PMID: 25099502.

[29] Joseph Odirichukwu Ugboaja, Charlotte Blanche Oguejiofor, Emmanuel Okwudili Oranu, Anthony Osita Igwegbe Mass media plays an important role in improving contraceptive use among Nigerian women. Nig JGen Prac 2018; 16 (2): 39-44.

[30] Ijeoma J Ibegbulam, Chinwendu C Akpom, Fidelia N Enem, Dora I Onyam Use of the Internet as a source for reproductive health information seeking among adolescent girls in secondary schools in Enugu, Nigeria Health Info Libr J 2018 Dec; 35 (4): 298-308. doi: 10.1111/hir.12242. Epub 2018 Nov 14. PMID: 30426642.

[31] Victor C. Strasburger, et al Sexuality, Contraception, and the Media Pediatrics, From the American Academy of Pediatrics, September 2010, VOLUME 126 / ISSUE 3 Pediatrics, American Academy of Pediatrics 2010; 126 (3). 
[32] Lindberg LD, Finer LB, Singh S, Santelli JS, Explaining recent declines in adolescent pregnancy in the United States: the contribution of abstinence and increased contraceptive use. Am J Public Health. 2007; 97 (1): 150-156.

[33] Victor C Strasburger, Amy B Jordan, Ed Donnerstein Children, adolescents, and the media: health effects Pediatr Clin North Am. 2012 Jun; 59 (3): 533-87 PMID: 22643165.
[34] Stern SE, Handel AD. Sexuality and mass media: the historical context of psychology's reaction to sexuality on the Internet. J Sex Res. 2001; 38 (4): 283-291.

[35] Ummulkhulthum A Bajoga, Ken L Atagame, Chinelo C Okigbo Media Influence on Sexual Activity and Contraceptive Use: A Cross Sectional Survey among Young Women in Urban Nigeria Afr J Reprod Health. 2015; 19 (3): 100-10. PMID: 26897918. 